\title{
The cell concept
}

\section{M. J. Kramer}

T.D., M.A. (Cantab.), Ph.D. (Lond.), F. Inst. Biol; formerly Senior Biology Master, City of London School; Senior Biology Master, Eton College; Lecturer in the Education Department, Exeter University

\section{J. K. Scott}

B.Sc., Ph.D. (Birmingham), Ph.D. (Cambridge); formerly Fellow of Wolfson College, Cambridge; formerly Biology Master, Eton College;

Principal Lecturer, Cambridgeshire College of Arts and Technology

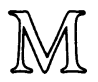

Macmillan Education 
This book is dedicated to the memory of John Baptist Kramer, M.I.Mech.E., M.I.E.E., who loved science and devised and furnished many important devices for use by Her Majesty's Armed Services and the British electrical industry between 1900 and 1945.

\section{(C) L. M. J. Kramer and J. K. Scott 1979}

All rights reserved. No part of this publication may be reproduced or transmitted, in any form or by any means, without permission.

First published 1979

Published by

Macmillan Education Limited

Houndmills Basingstoke Hampshire RG21 2XS

and London

Associated companies in Delhi Dublin

Hong Kong Johannesburg Lagos Melbourne

New York Singapore and Tokyo

British Library Cataloguing in Publication Data

Kramer, Lance Michael John

The cell concept. - (Foundations of biology).

1. Cells

I. Title

II. Scott, J K III. Series

$574.8^{\prime} 7$

QH581.2

ISBN 978-0-333-24194-3 ISBN 978-1-349-03989-0 (eBook)

DOI 10.1007/978-1-349-03989-0 


\section{Contents}

Acknowledgements iv

Preface v

1 What are cells? 1

2 Cellular composition and macromolecules 22

3 Fundamental biochemistry 44

4 Cells as transducers: part one the chloroplast 72

5 Cells as transducers: part two the mitochondrion 95

6 The exchange of materials 112

7 Control of the cell's activities 135

Suggestions for further reading $\quad{ }_{15}^{6}$

Index $\quad 159$ 


\section{Acknowledgements}

The authors wish to thank the following members of the University of Exeter for various forms of help: Professor J. Webster, Dr P. S. Uzzell, Dr P. Preece, Mr C. Carré and Mr R. Davey.

The author and publishers wish to acknowledge the following sources of photographs:

Dr. B E Juniper, Oxford University Botany School p. 79;

Kratos Ltd. (AEI Scientific Instruments) p. 6 right;

Dr. G F Leedale, Biphoto Associates p. 97;

Pyser Ltd. p. 6 left;

Science Museum p. 61 left;

C James Webb p. 18 above;

Prof. M H F Wilkins, Kings College Biophysics Dept. London p. 61 right; Taken from the publication McLeish \& Snoad, Chromosomes pp. 142, $143,144,145,146,147,148,149,150$;

Figure 29 is based on a diagram from Cells and Organelles by A B Novikoff and E Holtzman, published by Holt, Rinehart and Winston, 1970.

The publishers have made every effort to trace copyright holders, but if they have inadvertently overlooked any they will be pleased to make the necessary arrangement at the first opportunity. 


\section{Preface}

Foundations of biology aims to provide a complete pre-university course in biological science. Accordingly, the work is covered in a few handy volumes, not in a single bulky one or numerous monographs. The questions at the ends of the chapters are to test the comprehension of the material covered in the chapters and their contents are not necessarily similar to those set in biological examinations which often require knowledge in several branches of biology if they are to be answered properly. Suggestions are provided for further reading.

The course consists of five books written by experienced teachers with special knowledge of biological science, who believe through their experience that fresh approaches to teaching biology are desirable at pre-university level. The books in the series are:

The diversity of life

The cell concept

Heredity, development and evolution

Metabolism, movement and control

Man and the ecosystem.

A manual of practical work will also be provided, covering the required experimental biology related to each of the areas covered by the textbooks. The need to be certain of obtaining results at the minimum expense will be a main factor in determining the experiments selected.

Biologists will realise the difficulty of subdividing the course into a number of books and opinions will undoubtedly differ on how it should best be done. One difficulty is that a number of topics are based upon knowledge of others, so that if each book is to be helpful some overlap must occur with others in the series. In fact, the necessity for overlap has proved to be relatively small and where it occurs the treatment of topics is consistent from one book to another.

It is wise to remember that no branch of science is more 'fundamental' than any other, so no suggestion has been made that the books need to be studied in a given order. Teachers will be free to use them in any sequence or combination which suits their own courses.

All the authors concerned with the series have felt keenly the inadequacy of purely descriptive biology in giving insight into the basis of science today. It has been necessary therefore for them to introduce 
some mathematics, physics and organic chemistry to which biology is so closely related. The names of chemical compounds are accompanied by their new names under the IUPAC rules and in The cell concept there is an introduction to the new uses which seem difficult at first but which are in fact logical and easy to follow once the principles have been grasped.

L. M. J. Kramer

General Editor 